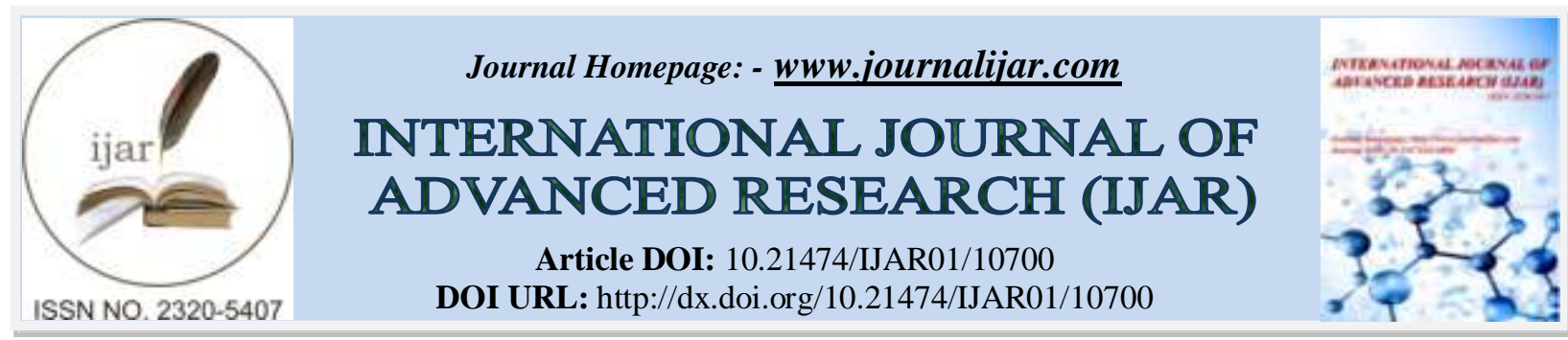

RESEARCH ARTICLE

\title{
ISOLATION OF LIPASE PRODUCING BACTERIA FROM OIL AND FAT CONTAMINATED SOIL SAMPLES AND ASSESSMENT OF THEIR LIPOLYTIC EFFICIENCY TOWARDS DIFFERENT SUBSTRATES
}

\author{
Rama T. ${ }^{1}$, Farissa D. ${ }^{1}$, Anil Kumar K.V. ${ }^{2}$ and Kiran Kumar D.J \\ 1. Department of Biotechnology, Government Science College, Bengaluru, India. \\ 2. Visveswarapura Institute of Pharmaceutical Sciences, Bengaluru, India.
}

\section{Manuscript Info}

Manuscript History

Received: 20 January 2020

Final Accepted: 22 February 2020

Published: March 2020

Key words:-

Bacillus, Bioremediation, Lipases,

Lipolytic Activity, Pseudomonas,

Staphylococcus

\begin{abstract}
Lipases find immense applications in food, dairy, detergent and pharmaceutical industries as Biotechnologically significant enzymes. In this regard, an effort was made to isolate bacteria from oil and fat contaminated soil samples. Further, three pure bacterial cultures were characterized and their lipolytic efficiency towards different substrates was assessed. Bacillus spp. degraded olive oil effectively and sunflower oil was significantly degraded by Pseudomonas spp. Of the three bacteria, Staphylococcus spp. showed maximum lipolytic activity towards diesel followed by kerosene as substrates. Hence, we can infer that isolated Staphylococcus spp.can be used effectively in the bioremediation of fuel oil spills.
\end{abstract}

Copy Right, IJAR, 2020,. All rights reserved.

\section{Introduction:-}

Enzymes are nature's catalyst, possessing unique properties that make them highly desirable for their application in the Biotechnology industry. Hydrolytic enzymes such as proteases, amylases, amidases, esterases and lipases hold a major share of the industrial enzyme market. Off late, lipases (triacylglycerolacyl hydrolase, E.C. 3.1.1.3) owing to their multifaceted properties have emerged as key enzymes in rapidly growing biotechnology industry. They find usage in a wide spectrum of industrial applications, such as food, detergent, biomedical sciences, and chemical industries (Jaeger et al., 1994, 1999; Pandey et al., 1999).

Lipases, triacylglycerol hydrolases act on the carboxyl ester bonds present in triacylglycerols to release fatty acids and glycerol under aqueous conditions. Since the long-chain triacylglycerols, natural substrates of lipases exhibit very low solubility in water the reaction is catalyzed at the lipid-water interface. Besides being lipolytic, lipases are highly specific as chemo, region and enantio selective catalysts also possess esterolytic activity and thus have a very diverse substrate range (Jaeger and Reetz, 1998; Beisson et al., 2000; Gupta and Soni, 2000).

Lipases are found in plants, animals and microorganisms. Microbial enzymes are more useful than enzymes derived from plants or animals sources (Joseph et al., 2008) due to the better stability, high yields and rapid growth of microorganisms. Some of the examples of lipolytic bacteria are Bacillus macerans, Bacillus subtilis, Pseudomonas fluorescens, Staphylococcus aureus, and Bacillus firmus. The bulk production of extracellular bacterial lipases is much easier. Hence, production of these enzymes has considerable commercial importance. Bacterial lipases are more economical and stable (Snellman et al., 2002), because of their ability to catalyze various reactions such as hydrolysis, esterification, interesterification, acidolysis, alcoholysis and aminolysis. Only a few bacterial strains are 
commercially exploited as wild or recombinant strains although a number of lipase-producing bacterial sources are available (Jaeger et al., 1994; Palekar et al., 2000).

\section{Materials and Methods:-}

\section{Sample collection:}

Oil and fat contaminated soil samples were collected from two sites Bangalore diary and Rajajinagar petrol bunk, Bengaluru, Karnataka, India.

\section{Isolation of bacterial strains:}

Soil samples were serially diluted and then plated on to tributyrin agar base containing $0.5 \%$ (w/v) peptone, $0.3 \%$ $(\mathrm{w} / \mathrm{v})$ yeast extract, $1 \%(\mathrm{v} / \mathrm{v})$ tributyrin and $2 \%$ agar and $\mathrm{pH} 7.0$ by spread plate method (Sarada Sarkar et al., 1998). Plates were incubated at $37{ }^{\circ} \mathrm{C}$ for two days. Pure cultures of the isolates were maintained on nutrient agar media (Beef extract, $\mathrm{NaCl}$, peptone, 2\% agar, $\mathrm{pH} 7.0$ ) and were sub cultured every 15 days.

\section{Screening of lipase producing bacterial strains:}

On the basis of Tributyrin agar plate assay method (TBA), the isolated bacterial strains were screened for their lipolytic activity. Tributyrin agar was purchased from Himedia. Isolates were grown on tributyrin agar base plates and incubated at $36{ }^{\circ} \mathrm{C}$ for 2 days to observe zone of clearance. The isolates showing maximum zone of clearance were selected for further analysis.

\section{Characterization of bacterial strains:}

Isolated bacterial strains were subjected to simple staining, Gram and endospore staining for morphological identification and biochemical tests such as Indole production test, Citrate utilization test, Fermentation of gas and acid test, Catalase test, Methyl red and Voges-Proskauer tests were performed as per the Bergey's Manual of Systematic Bacteriology (1984).

\section{Lipase Assay:}

Lipase activity was measured by titrimetric method using different substrates (Olive oil, Sunflower oil, Coconut oil, Petrol, Diesel, and Kerosene). Substrates (10\% v/v) were emulsified with gum arabic $(5 \% \mathrm{w} / \mathrm{v})$ in $100 \mathrm{mM}$ potassium phosphate buffer $\mathrm{pH}$ 7.0. The enzyme of $100 \mu \mathrm{L}$ was added to the emulsion and incubated for $15 \mathrm{~min}$ at $37{ }^{\circ} \mathrm{C}$. The reaction was stopped and fatty acids were extracted by addition of $2 \mathrm{~mL}$ of acetone: ethanol solution (1:1). The amounts of fatty acids liberated were estimated by titrating with $0.05 \mathrm{M} \mathrm{NaOH}$ until the $\mathrm{pH} 10.5$ was obtained using phenolphthalein as an indicator (Jensen, 1983).

\section{Statisticalanalysis:}

Data of the three trials were expressed as the mean values with standard deviation for each measurement. The data were also analyzed by one-way analysis of variance (One way-ANOVA). Tukey's multiple range tests were used for determination of significance of difference $(\mathrm{p}<0.05)$. Analysis was carried out using SPSS 11.0 (SPSS, Inc, Chicago, IL) software.

\section{Results:-}

In the year 2011, Mobarak-Qamsari et al. reported that an oily environment provides a better environment for growth and isolation of lipase producing microorganism. Hence, in this regard we made an attempt to isolate lipolytic microorganisms from oil and fat contaminated samples. We were able to isolatethree bacterial strains on the basis of morphological and biochemical characterization of microorganism fromoil and fat contaminated samples.The method of isolation was in par with isolation method adopted by Beller et al. (1996). Through morphological and biochemical tests (Table 1) the isolated three bacterial strains seemed to belong to the genera of Bacillus spp., Pseudomonas spp. and Staphylococcus spp. respectively. Olive oil has been regarded as one of the best inductors and substrate for lipase production among natural oils (Bornscheuer, 2002).

Table 1:- Morphological and biochemical characterization of isolates.

\begin{tabular}{|lccc|}
\hline Substrate, Test & \multicolumn{3}{c|}{ Results } \\
& Bacillus spp & Pseudomonas spp & Staphylococcus spp \\
\hline Gram Staining & Positive & Negative & Positive \\
Endospore Staining & Present & Absent & Absent \\
\hline
\end{tabular}




\begin{tabular}{|llll|}
\hline Morphology & Rods & Rods & Cocci \\
Citrate & Positive & Positive & Negative \\
Fermentation of gas and acid & Positive & Positive & Positive \\
Glucose & & & \\
Lactose & Negative & Negative & Positive \\
Indole & Slight acidic & Negative & Positive \\
Methyl Red & Negative & Negative & Negative \\
Voges Proskauer & Negative & Negative & Negative \\
Starch Hydrolysis & Positive & Negative & Negative \\
\hline
\end{tabular}

With Bacillus spp. the degradation of olive oil by lipase activity was observed to be significantly higher (Fig 1) followed by coconut oil, diesel, and sunflower oil. The Pseudomonas spp. showed marked increase in the lipase activity when sunflower oil was provided as a substrate (Fig 2). Other substrates including olive oil, kerosene, diesel, coconut oil and petrol followed the order. Among all the substrates, Staphylococcus spp. showed significantly high lipase activity against diesel followed by kerosene, olive oil, coconut oil, and petrol (Fig 3). The least lipase activity was observed when sunflower oil was provided as a substrate. Among all the substrates provided to the three bacterial specimens, highest lipase activity was observed in Staphylococcus spp. when diesel was used as the substrate (Table 2). The lipase activity by Staphylococcus spp. and Bacillus spp. against petrol and kerosene respectively were not significantly different (Table 2). It was also found that lipase activity exhibited by Bacillus spp. and Pseudomonas spp. against sunflower oil and coconut oil respectively did not differ significantly (Table 2).

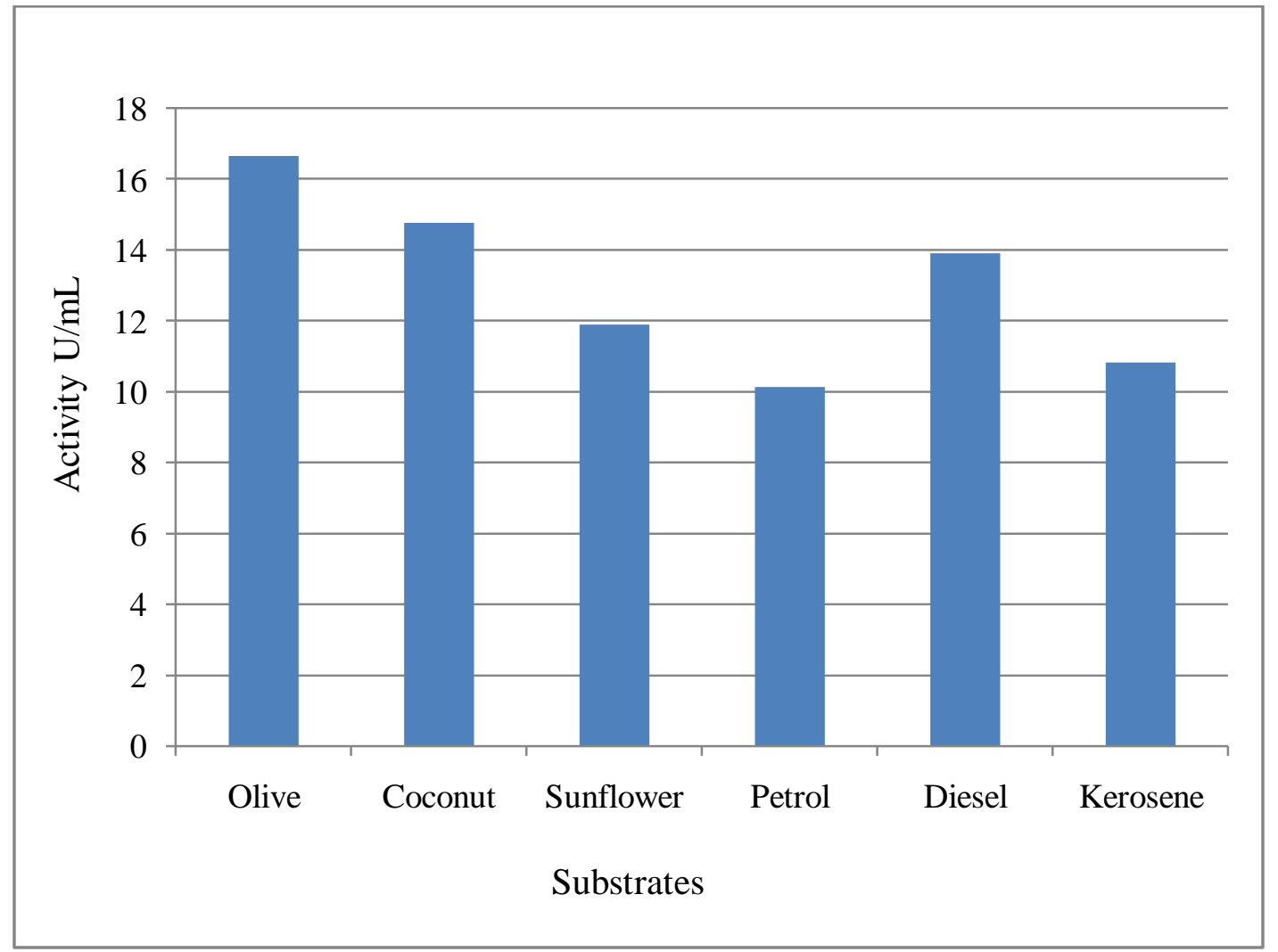

Fig 1:- Lipase activity in Bacillus spp. 


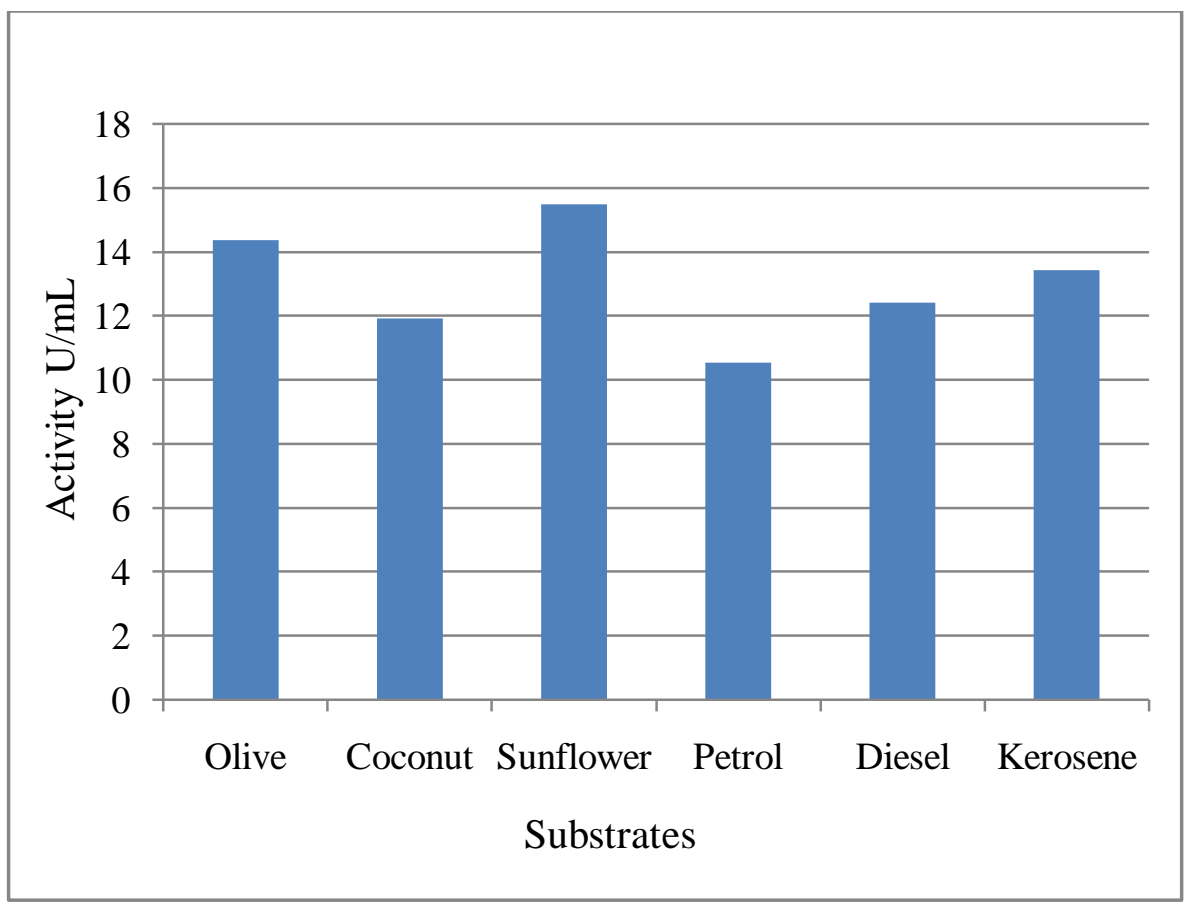

Fig 2:- Lipase activity in Pseudomonas spp.

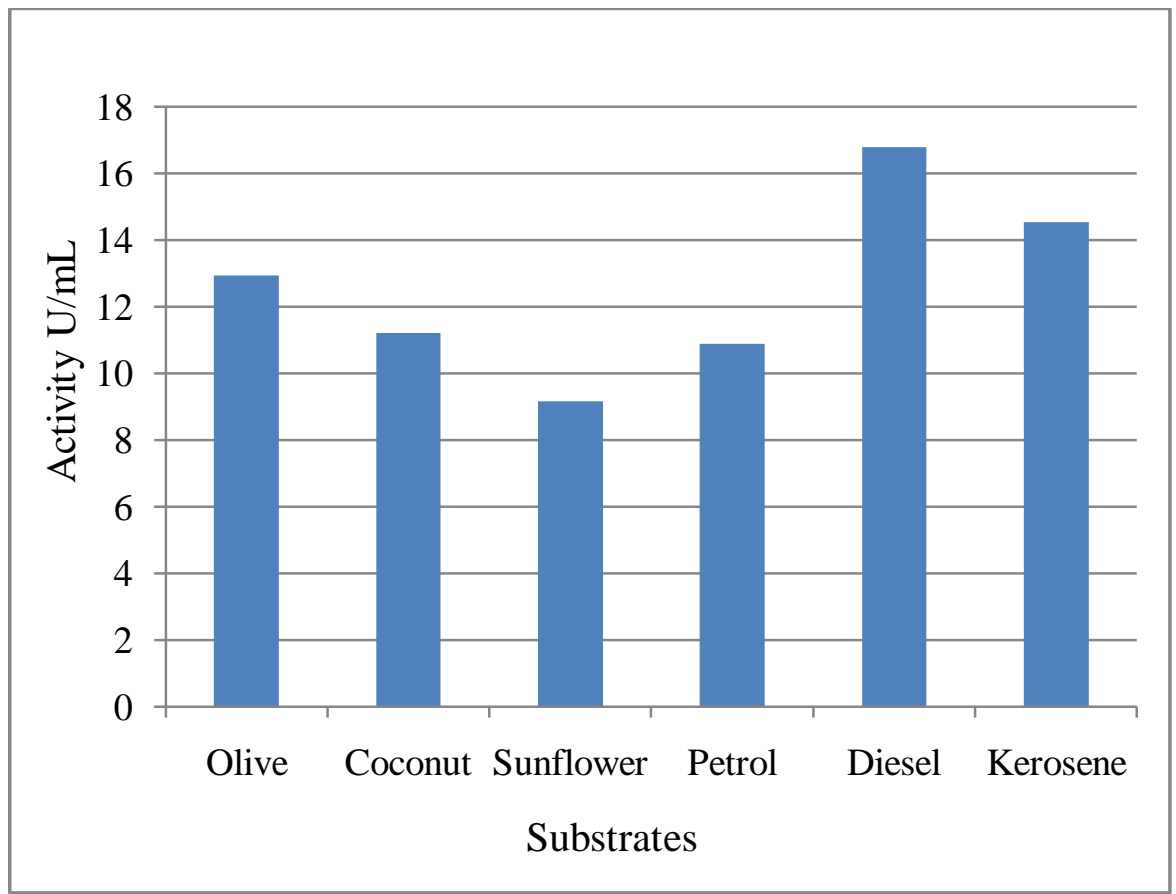

Fig 3:- Lipase activity in Staphylococcus spp.

Table 2:- Lipase activities on different oil substrates.

\begin{tabular}{|l|l|l|l|}
\hline Substrate & Staphylococcus Spp & Bacillus spp & Pseudomonas spp \\
\hline Olive oil & $12.92 \pm 0.03 \mathrm{~h}$ & $16.65 \pm 0.07 \mathrm{o}$ & $14.37 \pm 0.10 \mathrm{k}$ \\
\hline Coconut oil & $11.20 \pm 0.07 \mathrm{e}$ & $14.77 \pm 0.03 \mathrm{~m}$ & $11.92 \pm 0.03 \mathrm{f}$ \\
\hline Sunflower oil & $9.15 \pm 0.07 \mathrm{a}$ & $11.90 \pm 0.07 \mathrm{f}$ & $15.50 \pm 0.00 \mathrm{n}$ \\
\hline Petrol & $10.87 \pm 0.03 \mathrm{~d}$ & $10.12 \pm 0.03 \mathrm{~b}$ & $10.55 \pm 0.07 \mathrm{c}$ \\
\hline Diesel & $16.77 \pm 0.10 \mathrm{o}$ & $13.90 \pm 0.00 \mathrm{j}$ & $12.42 \pm 0.10 \mathrm{~g}$ \\
\hline
\end{tabular}


\begin{tabular}{|l|l|l|l}
\hline Kerosene & $14.52 \pm 0.031$ & $10.82 \pm 0.10 \mathrm{~d}$ & $13.45 \pm 0.00 \mathrm{i}$
\end{tabular}

Values with the same letter are not significantly different from each other $(\mathrm{p}<0.05)$

\section{Discussion:-}

Among all the substrates and the three bacterial specimens, the highest lipase activity was observed in Staphylococcus spp. when diesel was given as the substrate and hence may find probable acting as an excellent source for lipase used for degradation of oil spills. Degradation of hydrocarbons form petroleum polluted areas by Staphylococcus aureus, Micrococcus luteus, Lactobacillus acidophillus and Bacillus species has been reported by Ficker et al (1999). Bornscheuer (2002) referred olive oil has as one of the best inductors and substrate for lipase production among the natural oils available. Our study supports Bornscheuer findings as Bacillus spp. showed highest lipase activity for olive oil as substrate hence, may be used in detergents to remove oil dirt.

The greater production potential on a large scale made lipase enzymes toconsideras very important from the industrial point of view. From the recent research reports it is observed that submerged fermentation is found to be highly effective in large scale production of lipolytic enzymes (Snellman and Colwell, 2004) and it is apromising tool in Biotechnology field for the production of microbial enzymes (Tolan and Foody, 1999).The lipolytic enzymes produced through submerged fermentation are mostly used in thedetergent, food, pharmaceutical industries (Pandey et al., 1999; Ray, 2012).

\section{Conclusion:-}

Our study showed that isolate Bacillus spp. and Pseudomonas spp. can degrade vegetable oils effectively whereas Staphylococcus spp. can degrade fossil fuels effectivelyhence, could be probably used as an excellent source for lipase enzymes used in degradation of fuel oil spills in any environmental programs.

\section{Acknowledgements:-}

This work was supported by UGC-CPE fund, New Delhi, India.

\section{Conflict of Interests:-}

The authors declare that there is no conflict of interests regarding the publication of this paper.

\section{References:-}

1. Beisson, F., Tiss, A., Rivière, C. and Verger, R. (2000): Methods for lipase detection and assay: a critical review. Eur J Lipid Sci Technol., 133-153.

2. Beller, H. R., Spormann, A. M., Sharma, P. K., Cole, J. R. and Reinhard, M. (1996): Isolation and characterization of a novel toluene-degrading, sulfate-reducing bacterium. Appl. Environ Microb., 62(4): 11881196.

3. Bornscheuer, U.T. (2002): Microbial carboxyl esterases: classification, properties and application in biocatalysis. FEMS Microbiol Rev., 26 (1): 73-81.

4. Creig, R. N. and Holt, G. J. (1984): Bergey's Manual of Systematic Bacteriology. Williams and Willkins, London. Available from: https://www.worldcat.org/title/bergeys-manual-of-systematicbacteriology/oclc/9042846.

5. Gupta, J. K. and Soni, S.K. (2000): Industrial uses of enzymes. J Punjab Acad Sci., 2: 75-80.

6. Ficker, M., Krastel, K., Orlicky, S. and Edwards, E. (1999): Molecular characterization of a toluene- degrading methanogenic consortium. Appl Environ Microbiol., 65(12): 5576- 5585.

7. Gupta, J.K. and Soni, S. K. (2000): Industrial uses of enzymes. J Punjab Acad Sci., 2: 75-80.

8. Jaeger, K.E., Ransac, S., Dijkstra, B. W., Colson, C., Heuvel M van. and Misset O. (1994): Bacterial lipases. FEMS Microbiol Rev., 15: 29-63.

9. Jaeger, K.E. and Reetz, M.T. (1998): Microbial lipases form versatile tools for biotechnology. Trends Biotechnol., 16: 396-403.

10. Jaeger, K.E., Dijkstra, B.W. and Reetz, M.T. (1999): Bacterial biocatalysts: molecular biology, threedimensional structures and biotechnological applications of lipases. Annu Rev Microbiol., 53: 315- 351.

11. Jensen, R. G. (1983): Detection and determination of lipase (acylglycerol hydrolase) activity from sources. Lipids., 18(9): 650-657.

12. Joseph, B., Ramteke, P. W. and Thomas, G. (2008) : Cold active microbial lipases : Some hot issues and recent developments. Biotech Advances., 26: 457-470. 
13. Mobarak-Qamsari, E., Kasra-Kermanshahi, R. and Moosavi-nejad Z. (2011): Isolation and identification of a novel, lipase-producing bacterium, Pseudomnas aeruginosa KM110. Ran. J. Micro., 3(2): 92-98.

14. Palekar, A. A., Vasudevan, P.T. and Yan, S. (2000): Purification of lipase: a review. Biocatalysis Biotransformation., 18: 177-200.

15. Pandey, A., Benjamin, S., Soccol, C. R., Nigam, P., Krieger, N. and Soccol, U.T. (1999): The realm of microbial lipases in biotechnology. Biotechnol Appl Biochem., 29: 119-131.

16. Ray, A. (2012): Application of lipase in industry. Asian J Pharm Technol., 2(2): 33-37.

17. SaradaSarkar, B., Sreekanth, Shreya Kant., Rintu Banerjee and Bhattacharya, B.C. (1998): Production and optimization of microbial lipase. Bioprocess Engineering., 19: 29-32.

18. Snellman, E. A. and Colwell, R. R. (2004): Acinetobacter lipases: molecular biology, biochemical properties and biotechnological potential. J Ind Microbiol Biot., 31(9): 391-400.

19. Tolan, J. and Foody, B. (1999): Cellulase from submerged fermentation. Rec Progr Bioconv Ligno cellulosics., $41-67$. 